\title{
Application of Novel Low-Fouling Membranes for Fish Processing Wastewater Treatment and Comparison to PES Commercial Membranes in a Lab Scale Membrane Bioreactor
}

\author{
Jane Mburu' ${ }^{1, *}$, Ephraim Gukelberger ${ }^{2}$, Paul Mwangi ${ }^{1}$, Robert Kinyua ${ }^{1}$, Francesco Galiano ${ }^{3}$, Raffaella Mancuso ${ }^{4}$, Bartolo \\ Gabriele $^{4}$, Alberto Figoli ${ }^{3}$, and Jan Hoinkis ${ }^{2}$
}

${ }^{1}$ Institute of Energy and Environmental Technology, Jomo Kenyatta University of Agriculture and Technology, Kenya

${ }^{2}$ Centre of Applied Research (CAR), Karlsruhe University of Applied Sciences, Germany

${ }^{3}$ Institute on Membrane Technology, ITM-CNR, Italy

${ }^{4}$ Laboratory of Industrial and Synthetic Organic Chemistry (LISOC), Department of Chemistry and Chemical Technologies, University of Calabria, Italy

"Corresponding author: Jane Mburu, Institute of Energy and Environmental Technology, Jomo Kenyatta University of Agriculture and Technology, Kenya, Tel: +254 718038 827, E-mail: janemburu53@gmail.com

Received: 09 Mar, 2020 | Accepted: 25 Mar, 2020 | Published: 28 Mar, 2020

Citation: Mburu J, Gukelberger E, Mwangi P, Kinyua R, Galiano F, et al. (2020) Application of Novel Low-Fouling Membranes for Fish Processing Wastewater Treatment and Comparison to PES Commercial Membranes in a Lab Scale Membrane Bioreactor. Int J Water Wastewater Treat 6(1): dx.doi.org/10.16966/2381-5299.166

Copyright: ( 2020 Mburu J, et al. This is an open-access article distributed under the terms of the Creative Commons Attribution License, which permits unrestricted use, distribution, and reproduction in any medium, provided the original author and source are credited.

\begin{abstract}
This study aimed to apply a novel low-fouling membrane that was tested for the first time for treatment of fish processing wastewater in a Membrane Bioreactor (MBR) system. The aim was to demonstrate its improved performance and ability to resist fouling as part of a follow-up work where two studied commercial PES membrane modules showed significant fouling problems. A novel low fouling membrane was prepared by coating the surface of a PolyEtherSulphone (PES) membrane with a Polymerisable Bicontinuous Microemulsion (PBM). Performance test for PES membranes and PBM-coated membranes were conducted in an automated Ultrafiltration (UF) cross-flow testing cell using humic acid as model foulant. Further tests were conducted in a lab scale MBR unit. Characterization of chemical and surface properties of the two tested membranes was carried out using Attenuated Total Reflectance Infrared (ATR-FTIR) spectrophotometer and Contact Angle Measurements (CAM). The IR spectra confirmed the presence of PBM coating on the coated membranes while contact angle measurements demonstrated low contact angles indicating that hydrophilic property was achieved for the modified PBM membrane. The cross-flow fouling test showed low color intensity deposited on PBM coated membrane thus better resistance to fouling as was further confirmed with MBR experimental results which also showed the higher average COD removal efficiency of $96 \pm 1.1 \%$ for PBM module in comparison to $92 \pm 4.9 \%$ observed with the PES membrane module. The two tested PES and PBM membrane modules had COD in permeate mainly within the maximum allowable concentration of $<100 \mathrm{mg} / \mathrm{L}$ as per the WHO guidelines for wastewater reuse for irrigation. Percentage removal rate for nitrogenous compounds and $\mathrm{P}_{-} \mathrm{PO}_{4}{ }^{3-}$ in permeate was $88.1 \pm 1 \%$ and $83.6 \pm 1 \%$ for $\mathrm{PBM}$ membrane module and $84.5 \pm 2 \%$ and $69.3 \pm 3 \%$ for PES module respectively. PES membrane module showed significant fouling at critical flux of $7.3 \mathrm{~L} / \mathrm{m}^{2}$ at TMP of $230 \mathrm{mbar}$ in comparison to PBM module whose flux remained constant at higher flux above $350 \mathrm{mbar}$. This was an indication that PBM module had improved ability to resist fouling for a longer time and might be more economical in the long run for use in iMBR for the production of effluent to be used for irrigation agricultural fields.
\end{abstract}

Keywords: Novel low-fouling membranes; Polymerisable bicontinuous microemulsion; Fish processing wastewater treatment; Membrane bioreactor

\section{Introduction}

Management of wastewater is a major challenge faced in most of the urban cities in developing countries as a result of rapid urbanization with high population densities and poorly planned infrastructure for the management of wastewater [1]. In most cases, the existing sanitation facilities receive wastewater from municipal sewerage and from other undefined sources that include agricultural runoff and storm-water. In most cases, the wastewater treatment facilities are overloaded and therefore inadequate to effectively meet the demand for water and sanitation services required [2]. Fish processing industries in Kisumu, Kenya, for example, consume and release huge amounts of wastewater every day. Kisumu Water and Sewerage Company (KIWASCO) offer its service to Kisumu town but have inadequate capacity to effectively serve the existing industries that discharge huge amounts of wastewater on daily bases. In most cases, fish processing industries along the Lake Victoria shows discharge of raw effluent directly to the Lake as they have inadequate facilities for wastewater treatment [3]. This has resulted in severe pollution and eutrophication 
of the Lake Victoria shores with an extensive invasion of the water hyacinth plant that has destroyed the basin's ecosystem [3]. To reduce the impact, Kenya National Environmental Management Authority has resolved into closing down all the fish processing industries along Lake Victoria basin that lack proper wastewater treatment facilities and thus discharge raw effluent to Lake Victoria [4]. It is stipulated in Section 74 (2) of the Environmental Management and Co-ordination Act EMCA (1999) that "The proponent or owner of a trade or an industrial undertaking shall, before being granted a license to discharge effluents into the environment, install an appropriate plant for the treatment of such effluents before they are discharged into the environment" [5].

Membrane BioReactor (MBR) technology is a wastewater treatment method that integrates the biological Activated Sludge Process (ASP) with membrane filtration [6]. The system simultaneously retains the biomass whilst generating a clarified effluent through the process of MicroFiltration (MF) or UltraFiltration (UF) [6]. The technique is currently in use in countries such as e.g., Japan, China, South Korea, and the USA as an alternative method for the treatment of domestic sewage and a variety of industrial wastewaters [7]. Thanks to its small footprint as it does not require a sedimentation tank or clarifiers thus making it useful in towns and urban centers with limited land areas [8].

MBR technology is a promising wastewater treatment technique that could become a real-time solution for fish processing industries in Kenya. The technique can easily be adopted and installed as an indoor facility for treatment and reuse of fish processing wastewater as it has a small footprint and does not require large space for installation. However, according to a study conducted by Galiano F, et al. [9], the advancement of MBR technology has continually suffered a major drawback due to the problem of membrane fouling. Fouling is the deposition of solutes or suspended particles on the surface or into the pores of the membrane during the filtration process [9]. This results in a decline of the performance of the MBR system as the membranes suffer from flux losses caused by blocking of its pores [10]. Back flushing the filtrate through the membrane helps to eliminate surface foulants from the membrane [6]. However, when severe fouling occurs, chemical cleaning of the membranes is required to regain flux [7]. In the instance that flux is not restored, membranes have to frequently be replaced thus making the technology very expensive as this accounts for up to $30-50 \%$ of the operation cost [6]. There is, therefore, a need to mitigate the severe fouling of membranes to make MBR technology commercially viable for field application [9].

Membranes used for MBR technology are commonly made from polymeric materials as they are easy to configure to the required porosity [11]. However, polymeric membranes are generally hydrophobic making them highly susceptible to organic fouling as their surface adsorbs oils and protein residues in a wastewater stream [12]. The severity of membrane fouling is therefore highly dependent on the surface chemistry of the material (hydrophilicity) and nature of the surface (roughness) among other factors [6]. PolyEtherSulphone (PES) is one of the most common types of polymers used for making membranes for application MBR technology. This material has desirable properties such as reasonable thermal, chemical and mechanical resistance. However, PES has a hydrophobic surface that requires modification to help improve on its surface properties [12]. Based on this, researchers have come up with surface membrane modification techniques such as coating and grafting that enhance hydrophilic moiety of the membranes thus preventing fouling adhesion attributed to this phenomenon [13]. The coating technique is done by applying polymers with antifouling properties on the surface of the membrane to be modified [8]. On the other hand, grafting entails covalent immobilization of hydrophilic species from the solutions and onto the membrane surface [12].

Coating is preferably used for membrane surface modification since it does not involve extensive chemical treatment that may interfere with the structural properties of the base membrane [6]. In the current study a commercial PES membrane was modified by coating the surface with a Polymerizable Bicontinuous Microemulsion (PBM) [14].

The objective of this study was to test novel PBM coated membranes at pilot-scale with fish processing wastewater and compare their performance with commercial PES membranes. The aim was to demonstrate the improved performance of the modified membrane in terms of resistance to fouling and permeate water quality.

\section{Materials and Methods}

\section{Materials and methods}

The first part of this work was carried out by preparing a novel low fouling membrane through the Polymerizable Bicontinuous Microemulsion (PBM) technique by use of UV light (UV-LED). All chemicals used for this work were analytical grade with purity higher than $98 \%$, purchased from Sigma-Aldrich. The Acryloyloxy Undecyl Triethylammonium Bromide (AUTEAB) polymerizable surfactant was prepared according to the procedure described elsewhere [15].

Technical specifications for flat Martin Cube PES membrane modules: PES commercial and PBM coated membranes were assembled into modules to be tested in MBR. The technical specifications for PES membrane modules used for this work are shown in table 1 .

The second part of this work was carried out to test for the first time the performance of PBM-coated membranes for treatment of fish processing wastewater in a small lab scale Immersed Membrane Bioreactor (iMBR) unit in the JKUAT IEET lab. The aim was to demonstrate its improved performance and ability to resist fouling as part of a follow-up work where PES membrane modules showed significant fouling problems [10]. Materials and apparatus used for wastewater treatment process study included a lab scale iMBR unit constituting a 97 L Polyvinyl chloride (PVC) aeration tank interfaced to a denitrification tank, a PES and PBM-coated CUBE Mini $0.45 \mathrm{~m}^{2}$ Flat Sheet (FS) modules (www.martin-membrane.de).

\section{Preparation of PBM}

PBM was prepared as per the method developed by Galiano, et al. [9]. In this process, $41 \%$ of deionized water (DI) with a conductivity of

Table 1: Technical specifications for PES membrane from Martin Cube modules.

\begin{tabular}{|l|l|}
\hline \multicolumn{1}{|c|}{ Technical data } & \multicolumn{1}{|c|}{$\begin{array}{c}\text { Martin CUBE Mini membrane } \\
\text { module }\end{array}$} \\
\hline Active layer & PES \\
\hline Support layer & PE/PP \\
\hline MWCO $(\mathrm{kDa})$ & $150 \mathrm{kDalton}$ \\
\hline $\begin{array}{l}\text { Pore size }(\mu \mathrm{m}) / \text { Pore size }(\mu \mathrm{m}) \\
\text { norminal-maximal }\end{array}$ & $0.035-0.1 \mu \mathrm{m}$ \\
\hline Membrane area & 5 panels of $0,09 \mathrm{~m}^{2}$ each, total $0.45 \mathrm{~m}^{2}$ \\
\hline Gaps between the membranes & $6 \mathrm{~mm}$ \\
\hline Water permeability $\left(\mathrm{L} /\left(\mathrm{m}^{2} \mathrm{~h}\right.\right.$ bar $)$ & $>280$ \\
\hline
\end{tabular}

Source: www.martin-membrane.de 
$5 \mu \mathrm{S} / \mathrm{cm}$ was placed into a $25 \mathrm{ml}$ reagent bottle. $21 \%$ monomer MMA was added to the deionized water to form a mixture of oil and water and $10 \%$ of co-surfactant HEMA was added. 3\% of EDMA (a crosslinker) was then added and followed by $25 \%$ of AUTEAB surfactant to make a clear and transparent PBM solution [9]. After preparation, the $\mathrm{PBM}$ solution was kept at a temperature between $20^{\circ} \mathrm{C}$ and $25^{\circ} \mathrm{C}$ ready for the polymerization process.

Polymerization of the PBM solution was carried out using UV based initiators as per the method developed by Galiano F, et al. [14]. UV based PBM was prepared by adding $63 \mathrm{mg}$ of photoinitiator (Irgacure 184) to $3.5 \mathrm{~g}$ of PBM solution. The mixture was mechanically stirred until the photoinitiator was dissolved and the solution was finally ready for membrane coating.

Membrane coating was conducted in a membrane casting chamber filled with gaseous nitrogen $\left(\mathrm{N}_{2}\right)$.The casting chamber was equipped with a temperature sensor and an oxygen sensor. The casting chamber was connected to a thermostat to facilitate control of temperature between $24 \pm 1{ }^{\circ} \mathrm{C}$. Other components inside the chamber included a Casting knife with $4 \mu \mathrm{m}$ wet coating layer thickness, a glass plate, cooling fan and a UV-LED lamp.

Preparation of PBM coated membrane for fish processing wastewater treatment: The PBM coated membrane was prepared by casting the coating solution on PES membrane attached to a glass plate that was placed into the casting chamber purged with nitrogen gas to keep oxygen level below 1\%. The PBM solution with photo initiators added was cast on the PES membrane surface with a casting knife of $4 \mu \mathrm{m}$. The size of the casting knife to be used was determined based on the optimization results obtained by Galiano, et al. [14]. The membrane was lifted to the desired height and was exposed to ultraviolet (UV) light of wavelength $365 \mathrm{~nm}$. The irradiation time was set to $60 \mathrm{sec}$ to ensure a complete curing of the layer. This was in agreement with the findings made by Galiano F, et al. [14]. In their study, the authors discovered that UV photoinitiated polymerization process took a shorter curing time than the REDOX-based process thus is more viable for commercial scale-up. Based on these findings, the UV photo initiated polymerization process was adopted for the current study.

\section{Characterization of PES and PBM-coated membranes:}

Chemical characterization: The chemical composition for the PES membrane and PBM-coated membrane was analyzed using the Attenuated Total Reflectance Infrared (ATR-FTIR) spectrophotometer (Bruker TENSOR II, Germany). The aim was to identify the presence of a variety of peaks being characteristic for the PBM coating on the modified membrane. The ATR-FTIR spectrums obtained from the two tested membranes were compared.

Surface characterization: The CAM instrument (Data physics SCA 20, Germany) was used to evaluate the water contact angle of the investigated membranes. The process entailed measurement of the surface contact angle of a drop of water placed on the active side of PES membranes and coated PBM membrane thus determine its degree of hydrophilicity (wettability). This was carried out using the sessile drop method where $5 \mu \mathrm{L}$ of deionized water was dropped on to the active side of PES membranes using a microliter syringe. The captured drop image was analyzed using a drop profile fitting method within a span of 0-8 seconds. At least 3 measurements for contact angle were taken for each sample. The mean value and standard deviation for the measurements were calculated to determine their significant difference.

\section{Preliminary fouling test for PES and PBM-coated membrane using an automated UltraFiltration (UF) cross-flow testing cell}

Preliminary tests for water permeability and fouling propensity was conducted for PES and PBM coated membranes using automated cross-flow testing cell (SIMAtec GmbH, Germany), see figure 1. This was carried out by inducing fouling on the membrane surface using humic acid with a concentration of $100 \mathrm{mg} / \mathrm{L}$. In this process, two membranes (commercial and PBM coated) with an active membrane area of $0.0085 \mathrm{~m}^{2}$ each were placed in series in the flat membrane test cell. The experiment was conducted continuously for $24 \mathrm{~h}$ by recirculating permeate and concentrate coming out of the membrane module back to the feed tank. Besides permeate water flux the visual appearance of the membranes after testing with humic acid was compared and the intensity of their color noted as an indication of the membrane's fouling propensity.

Testing PBM membrane module for fish processing wastewater treatment in the iMBR and comparison of its performance to PES commercial membrane: In this part of the study, a sequential test for PES and PBM membrane module was conducted using the CUBE Mini $0.45 \mathrm{~m}^{2}$ flat sheet membrane module of 5 panels and a CUBE mini of same dimension laminated with PBM coated PES membranes. The PBM-coated membrane module was tested for the first time for the treatment of fish processing wastewater in a lab-scale Immersed Membrane Bioreactor (iMBR) unit in the JKUAT-IEET laboratory. The experiment was conducted continuously in the iMBR for 80 days starting from February to May 2019.

The process was initiated by collection of raw fish processing wastewater (feed) from Makindi fish farm as described by Mburu J, et al. [10]. Tests were conducted to ascertain the quality of the wastewater before and after treatment. The COD for the feed and permeate was measured using COD cell tests (Method 1.14541) from Merck KGaA (Germany). The range of measurement was $25-1,500 \mathrm{mg} / \mathrm{L}$ (COD) with a standard deviation of $\pm 0.65 \%$. The COD removal rate was calculated as shown in Equation 1.

$$
\begin{gathered}
\% \mathrm{COD} \quad(\text { Removal rate })=1-\left(\mathrm{COD}_{\mathrm{P}} / \mathrm{COD}_{\mathrm{F}}\right) \times 100 \\
\ldots \ldots \ldots \ldots \ldots \ldots \ldots \ldots \text { Equation } 1
\end{gathered}
$$

Where $\mathrm{COD}_{\mathrm{P}}$ is the $\mathrm{COD}$ of permeate and $\mathrm{COD}_{\mathrm{F}}$ is the $\mathrm{COD}$ of the feed.

The $\mathrm{N}$-compounds for the feed and permeate, were analyzed as nitrate-nitrogen $\left(\mathrm{NO}_{3}^{-}-\mathrm{N}\right)$ and ammonium-nitrogen $\left(\mathrm{NH}_{4}{ }^{+}-\mathrm{N}\right)$. All $\mathrm{NH}_{4}^{+}-\mathrm{N}$ was analyzed with cell tests (Method: 1.14558) from Merck KGaA (Germany). The range of measurement was $0.2-8$ $\mathrm{mg} / \mathrm{L}\left(\mathrm{NH}_{4}{ }^{+}-\mathrm{N}\right)$ with a standard deviation of $\pm 1.0 \%$. The $\mathrm{NO}_{3}{ }^{-} \mathrm{N}$ was analyzed with cell tests (Method: 1.14542) from Merck KGaA (Germany). The method has a measuring range of $0.5-18 \mathrm{mg} / \mathrm{L}\left(\mathrm{NO}_{3}\right.$ $-\mathrm{N}$ ), with a standard deviation of $\pm 1.5 \%$. Percentage removal rate for nitrogenous compounds and phosphates $\left(\mathrm{P}_{-} \mathrm{PO}_{4}^{-3} \mathrm{mg} / \mathrm{l}\right)$ in permeate was calculated as shown in Equation 2 and 3 respectively.

\footnotetext{
» Nitrogenous compounds (Removal rate) $=1-\left(\mathrm{N}_{\mathrm{p}} / \mathrm{N}_{\mathrm{F}}\right) \times$ $100 \ldots \ldots \ldots \ldots \ldots . . . . . .$. Equation 2
}

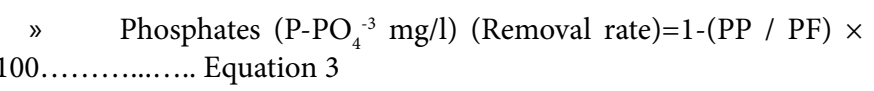

Where $\mathrm{N}_{\mathrm{p}}$ is the $\mathrm{N}$ - Nitrogenous compounds of permeate and $\mathrm{N}_{\mathrm{F}}$ is the N- Nitrogenous compounds of the feed.

Where $\mathrm{P}_{\mathrm{P}}$ is the $\mathrm{P}$ - Phosphates of permeate and $\mathrm{P}_{\mathrm{F}}$ is the $\mathrm{P}$ Phosphates of the feed. 


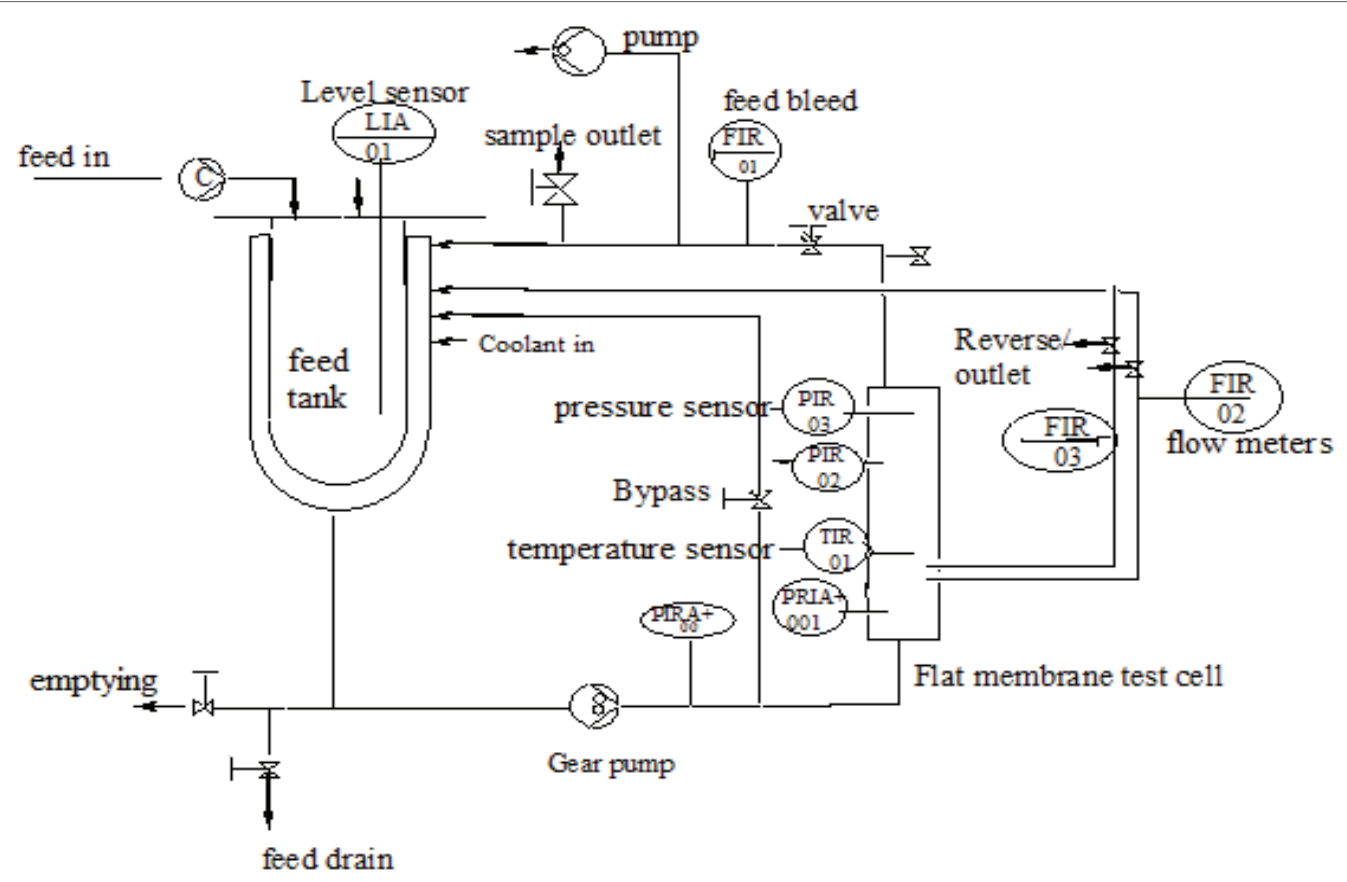

Figure 1: Schematic diagram of the automated ultrafiltration (UF) cross-flow testing cell (SIMAtec GmbH, Germany).

The initial test for the raw fish processing wastewater was carried out within 3 hours after sampling and another test was done before feeding the raw fish processing wastewater to the MBR in order to account for the possible changes in nitrogen balance. The treatment process was conducted in a lab-scale Immersed Membrane Bioreactor (iMBR) illustrated in figure 2 .

As illustrated in figure 2, the iMBR system constituted of $97 \mathrm{~L}$ PolyVinyl Chloride (PVC) aeration tank. The CUBE Mini $0.45 \mathrm{~m}^{2}$ flat sheet PES and PBM-coated CUBE Mini module were submerged and tested in sequence in the MBR system. The iMBR system permeate line for the tested module was installed with an analog rotameter with a volume flow indicator ranging 0.5 to $5 \mathrm{~L} / \mathrm{h}$, a manometer and permeate (suction) pump having a speed control of 0.2 to $2 \mathrm{~L} / \mathrm{h}$. An air pump with a flow volume of $100 \mathrm{~L} / \mathrm{min}$ was connected to the air bubbler system. The iMBR system had $\mathrm{pH}$ meters, temperature sensor and electric conductivity cell model installed in the permeate lines. The iMBR system is described in detail by Mburu J, et al. [10].

Critical flux test for PBM and PBM membrane module using fish processing wastewater in the iMBR

A sequential test for PES and PBM membrane module was conducted in the MBR to determine the critical flux for the tested modules. This was achieved by increasing the speed of the suction pump from $0.5 \mathrm{~V}(25.3 \mathrm{ml} /$ minute $)$ to $1.11 \mathrm{~V}$ ( $55.6 \mathrm{ml} /$ minute) with time intervals of 24 hours (where $5000 \mathrm{ml} /$ minute $=99$ Volts). Critical flux was observed by plotting a curve for flux $v s$. TMP.

\section{Experimental Results}

Chemical composition analysis for PES commercial membrane and PBM-coated membranes

Chemical composition analysis for the PES membrane and PBM-coated membrane was conducted using the Attenuated
Total Reflectance Infrared (ATR-FTIR) spectrophotometer. The IR spectrums observed for PES and PBM-coated membranes were compared using an overlay as shown in figure 3 in order to recognize characteristic peaks.

As seen in figure 3, the IR spectrum for the PBM-coated membrane showed a strong peak absorbing at $1724 \mathrm{~cm}^{-1}$ (illustrated by the red line) characteristic of the carbonyl functional group $(\mathrm{C}=\mathrm{O})$ found in the chemical structure of acrylate groups present in PBM coating. The PBM mixture constitutes MMA, the co-surfactant HEMA, the polymerisable surfactant AUTEAB and a cross-linker (EGDMA) all bearing an acrylate functional group that is not present in PES commercial membrane [14]. Notable for this experiment, the carbonyl peak was absent in the spectra of unmodified PES commercial membrane illustrated (blue line) in figure 3. These findings are in line with what was reported by Galiano, et al. [14] and confirm the presence of the PBM coating on the PES surface.

\section{Contact angle measurement for PES and PBM membranes}

Sessile drop Contact Angle Measurement (CAM) was conducted on the PES commercial membrane and on the modified PBM-coated membranes to access their relative wettability. The results showed higher hydrophilic moiety for the PBM membrane in comparison to the PES unmodified membrane. These results are illustrated in table 2.

As can be seen in table 2, PBM membranes had an average Contact Angle (CA) in the range of $31.6 \pm 2.2^{\circ}-34.1 \pm 2.8^{\circ}$ in comparison to $60.2 \pm 2.1^{\circ}-56.4 \pm 2.1^{\circ}$ observed with PES membranes. The reduction in CA for PBM membranes in comparison to PES commercial membrane was from $60.2^{\circ}$ to $31.6^{\circ}$ which was a change of about $48 \%$ respectively. A significant difference was noted in the mean values for the CA observed from the two tested PES and PBM-coated membranes with $\left(\mathrm{t}_{\text {calculated }}>\mathrm{t}_{\text {critical }}\right)$ for paired T-test (at $95 \%$ confidence level) as illustrated in table 2. The low Contact Angle (CA) observed in PBM

Citation: Mburu J, Gukelberger E, Mwangi P, Kinyua R, Galiano F, et al. (2020) Application of Novel Low-Fouling Membranes for Fish Processing Wastewater Treatment and Comparison to PES Commercial Membranes in a Lab Scale Membrane Bioreactor. Int J Water Wastewater Treat 6(1): dx.doi.org/10.16966/2381-5299.166 


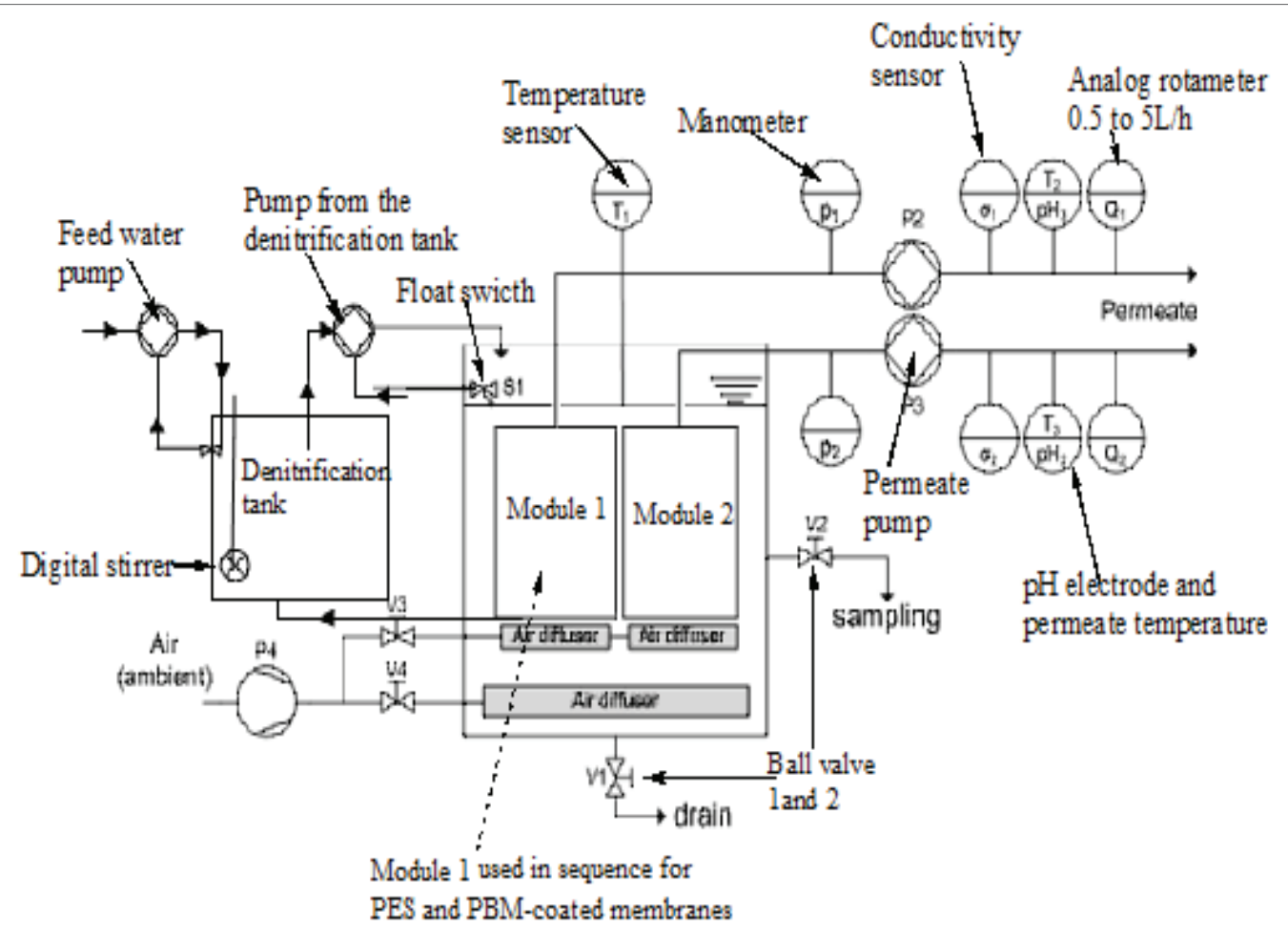

Figure 2: Schematic diagram for the Immersed Membrane Bioreactor (iMBR).

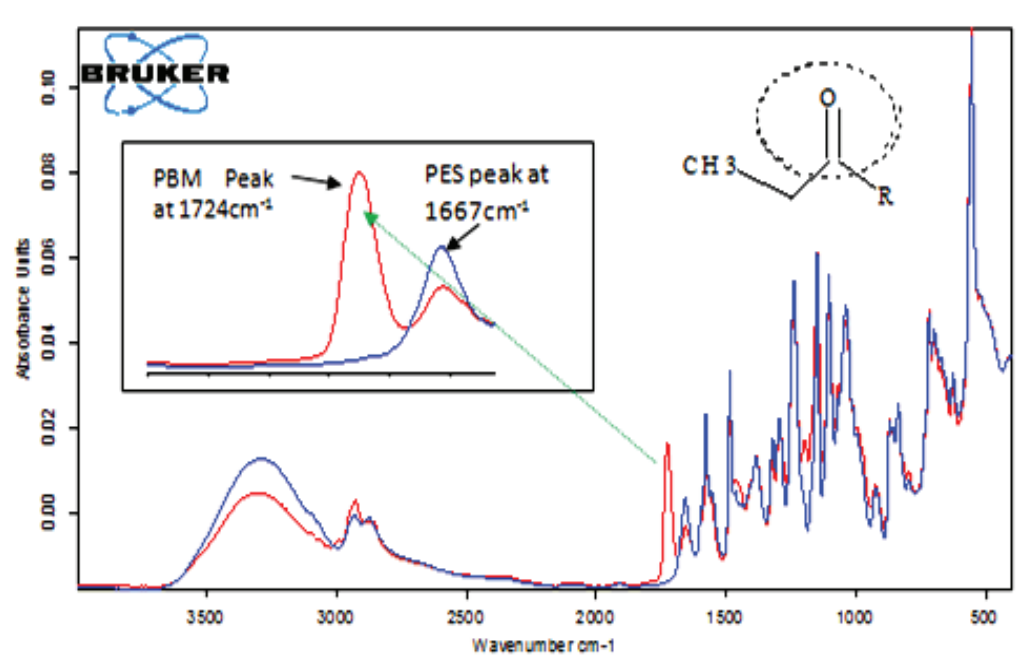

Figure 3: IR spectra of PES commercial and PBM-coated membrane.

coated membranes was attributed to the presence of hydroxyl $(-\mathrm{OH})$ and ammonium $\left(\mathrm{NEt}_{3}^{+}\right)$groups in the membrane surface. These were introduced to the membrane surface by application of PBM coating prepared using co-monomer (HEMA) and surfactant (AUTEAB) that comprised $\mathrm{OH}$ and $\mathrm{NEt}_{3}{ }^{+}$functional groups in their chemical structure respectively. These have an effect on decreasing contact angle improving the hydrophilic nature of membrane surface. These findings have also been confirmed by other authors [16].
Preliminary fouling test results for PES and PBM coated membrane

Preliminary fouling test was conducted using humic acid as it constitutes a brown color and was therefore used to treat the membranes and evaluate their fouling characteristic by comparing the intensity of color deposited on membrane surface after treatment. The visual observations made are shown in figure 4. 
Table 2: Contact angle measurement (CAM) PES and PBM coated membrane surface at $\mathrm{t}=0.8 \mathrm{~s}$.

\begin{tabular}{|c|c|c|c|}
\hline \multirow{2}{*}{$\begin{array}{c}\text { Membrane PES } \\
\text { commercial } \\
\text { Average contact angle (CA) } \\
\text { and Standard Deviation }\end{array}$} & \multirow{2}{*}{$\begin{array}{l}\text { PBM } 4 \mu \mathrm{m} \text { coated } \\
\text { membrane, } \\
\text { Average contact } \\
\text { angle (CA) and } \\
\text { standard deviation }\end{array}$} & \multicolumn{2}{|c|}{$\begin{array}{l}\text { Comparison of } \\
\text { average contact angle } \\
\text { (CA) between PES and } \\
\text { PBM membranes }\end{array}$} \\
\hline & & $\mathbf{t}_{\text {calculated }}$ & $\mathbf{t}_{\text {critical }}$ \\
\hline $60.2 \pm 2.1$ & $33.7 \pm 3.3$ & 13.8 & 2.78 \\
\hline $58.7 \pm 2.5$ & $32.4 \pm 3.3$ & 13.4 & 2.78 \\
\hline $56.4 \pm 2.1$ & $31.6 \pm 2.2$ & 14.1 & 2.78 \\
\hline $55.8 \pm 1.2$ & $34.1 \pm 2.8$ & 13.1 & 2.78 \\
\hline
\end{tabular}

As can be seen in figure 4, the color intensity deposited on the PES membrane surface was high in comparison to that of the PBM coated membrane signifying the humic acid layer deposited. Humic acid is constituted of aromatic compounds that make it hydrophobic and thus had lower binding affinity for PBM module attributed to improved hydrophilicity of its surface as was demonstrated with Contact Angle Measurements (CAM) in table 2. The PBM-coated membrane surface therefore demonstrated improved ability for foulant rejection as illustrated in figure 4 . The fouling phenomenon was confirmed to be less pronounced on the surface of the PBM coated membrane in comparison to that of the commercial PES membrane. These findings have also been confirmed by others [9]. The author worked on membrane surface modification via PBM for treatment of textile dye wastewater.

\section{Cross flow water permeability results for PES and PBM coated membranes}

The preliminary test for water permeability was conducted for PES and PBM coated membranes using automated UltraFiltration (UF) cross-flow testing cell (SIMAtec GmbH, Germany). The results observed are illustrated in figure 5 .

As can be seen in figure 5, the water permeability (WP) for PES membrane was higher and ranging between $180-244 \mathrm{~L} /\left(\mathrm{m}^{2} \mathrm{~h}\right.$ bar $)$ (black line) at the beginning of the experiment. However, towards the end of the experiment a gradual decrease in WP was observed for PES membrane and was in the range of $126-144 \mathrm{~L} /\left(\mathrm{m}^{2} \mathrm{~h}\right.$ bar) (black line). The $4 \mu \mathrm{m}$ PBM-coated membrane exhibited relatively constant WP varying between $56-79 \mathrm{~L} /\left(\mathrm{m}^{2} \mathrm{~h}\right.$ bar) (red line) for the period the experiment was conducted and was notably lower in comparison to that of the PES membrane and it showed a slight increase. This was attributed to the increased thickness of PBM coating thus resulting to an increased mass resistance to influent flow through the membrane.

\section{Characteristics of the fish processing wastewater used as feed for the iMBR experiments}

Fish processing wastewater was analyzed within 3 hours after sampling and before feeding to the iMBR to ascertain its quality and also account for the expected change in nitrogen balance during storage time. Tables 3 and 4 present the wastewater characteristic at collection point and in the feed tank for experiment conducted with the iMBR using the PES module.

In the same manner an analysis was conducted on wastewater used for the experiment conducted in the iMBR using the PBM module. Tables 5 and 6 , presents the wastewater characteristic at collection point and in the feed tank.

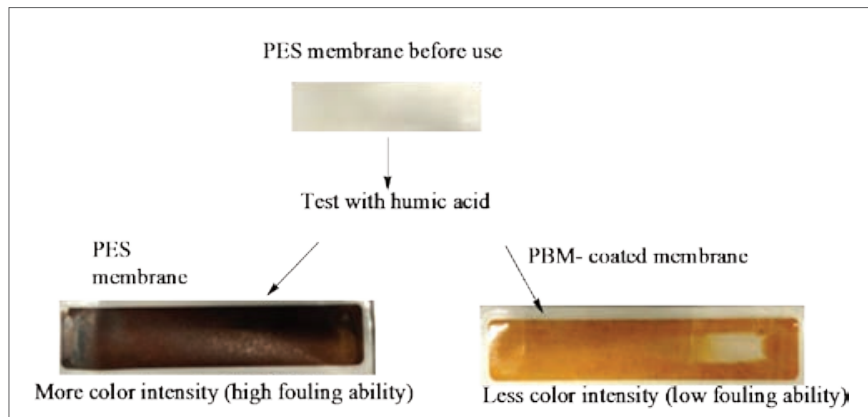

Figure 4: Comparison of color intensity deposited on PES and PBMcoated membrane after treatment with humic acid

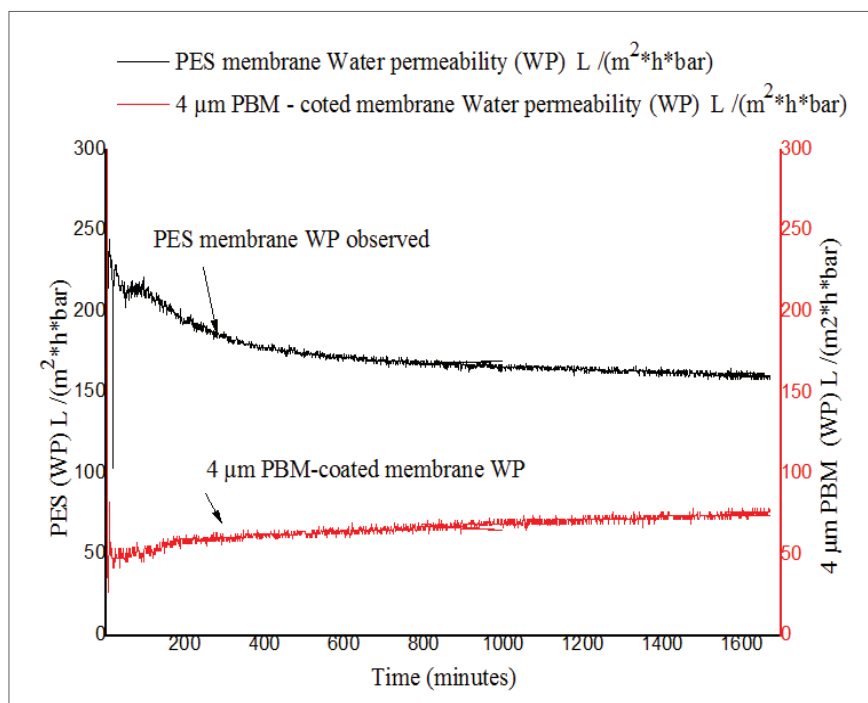

Figure 5: Comparison of water permeability for PES, $4 \mu \mathrm{m}$ PBM membranes with operation time.

As seen in Tables 3 and 5, nitrate-nitrogen $\left(\mathrm{NO}_{3}^{-}-\mathrm{N}\right)$ was high in the raw fish processing wastewater analyzed within 3 hours after sampling. However, the concentration changed as ammoniumnitrogen $\left(\mathrm{NH}_{4}^{+}-\mathrm{N}\right)$ levels increased and nitrate decreased for the samples drained in the feed tank as illustrated in table 4 and 6 . This was attributed to shifting via anoxic to anaerobic conditions in the feed tank that suppressed the activity of aerobic nitrifying bacteria thus causing a rise in $\mathrm{NH}_{4}{ }^{+}-\mathrm{N}$ mainly during storage. Other parameters such as $\mathrm{pH}$ and conductivity $(\mu \mathrm{S} / \mathrm{cm})$ remained relatively constant at the collection point and in the feed tank as illustrated in table 6 .

\section{Experimental results for the treatment process conducted in} the iMBR unit using fish processing wastewater

Results of PBM coated membranes on water permeability, flux and Trans Membrane Pressure (TMP) with operation time and comparison to PES commercial membrane: In this section, the performance of the PES UF commercial membrane and PBM coated membrane was analyzed and the results are compared as illustrated in figure 6.

As illustrated in figure 6, both systems were operated separately at a relatively constant low flux with that of the PBM module varying from $4.4 \mathrm{~L} / \mathrm{m}^{2 *} \mathrm{~h}-4.9 \mathrm{~L} / \mathrm{m}^{2 \star} \mathrm{h}$ (green line) in comparison to $5.6 \mathrm{~L} / \mathrm{m}^{2 *} \mathrm{~h}-7.8 \mathrm{~L} /$ $\mathrm{m}^{2} \mathrm{~h}$ (red line) observed for PES module. The PBM coated membrane

Citation: Mburu J, Gukelberger E, Mwangi P, Kinyua R, Galiano F, et al. (2020) Application of Novel Low-Fouling Membranes for Fish Processing Wastewater Treatment and Comparison to PES Commercial Membranes in a Lab Scale Membrane Bioreactor. Int J Water Wastewater Treat 6(1): dx.doi.org/10.16966/2381-5299.166 
Table 3: Fish processing wastewater characteristic at collection point (results obtained within 3 hours after sampling) for PES module experiment.

\begin{tabular}{|l|c|c|c|c|}
\hline $\begin{array}{c}\text { Measured } \\
\text { values }\end{array}$ & February 2019 & March 2019 & April 2019 & May 2019 \\
\hline $\mathrm{NH}_{4}^{+}-\mathrm{N}(\mathrm{mg} / \mathrm{l})$ & $11.2 \pm 0.1$ & $9.1 \pm 0.3$ & $12.1 \pm 0.3$ & $10.1 \pm 0.5$ \\
\hline $\mathrm{NO}_{3}^{-}-\mathrm{N}(\mathrm{mg} / \mathrm{l})$ & $20.1 \pm 0.5$ & $20.4 \pm 0.1$ & $18.7 \pm 0.4$ & $17.3 \pm 0.5$ \\
\hline $\mathrm{PO}_{4}^{-3}-\mathrm{P}(\mathrm{mg} / \mathrm{l})$ & $10.3 \pm 0.5$ & $8.3 \pm 0.3$ & $8.7 \pm 0.7$ & $8.1 \pm 0.3$ \\
\hline $\mathrm{pH}$ & $7.0 \pm 0.5$ & $6.9 \pm 0.5$ & $7.0 \pm 0.5$ & $7.2 \pm 0.5$ \\
\hline $\begin{array}{l}\text { Conductivity } \\
(\mu \mathrm{S} / \mathrm{cm})\end{array}$ & $376 \pm 0.5$ & $317 \pm 0.5$ & $369 \pm 0.5$ & $391 \pm 0.6$ \\
\hline
\end{tabular}

Table 4: Fish process wastewater characteristics in feed tank for experiment conducted with PES module.

\begin{tabular}{|l|c|c|c|c|}
\hline \multicolumn{1}{|c|}{$\begin{array}{c}\text { Measured } \\
\text { values }\end{array}$} & February 2019 & March 2019 & April 2019 & May 2019 \\
\hline Dry mass (g/L) & $2.76 \pm 0.2$ & $2.08 \pm 0.6$ & $1.22 \pm 0.3$ & $1.12 \pm 0.5$ \\
\hline $\mathrm{COD}(\mathrm{mg} / \mathrm{L})$ & $2042 \pm 121$ & $1398 \pm 101$ & $1593 \pm 137$ & $1118 \pm 115$ \\
\hline $\mathrm{BOD}_{5}(\mathrm{mg} / \mathrm{L})$ & $526 \pm 0.5$ & $336 \pm 0.5$ & $363 \pm 0.9$ & $278 \pm 0.6$ \\
\hline $\mathrm{NH}_{4}^{+}-\mathrm{N}(\mathrm{mg} / \mathrm{l})$ & $32.1 \pm 0.1$ & $30.7 \pm 0.5$ & $32.1 \pm 0.3$ & $28.2 \pm 0.2$ \\
\hline $\mathrm{NO}_{3}^{-}-\mathrm{N}(\mathrm{mg} / \mathrm{l})$ & $1.9 \pm 0.5$ & $2.9 \pm 0.1$ & $3.8 \pm 0.5$ & $3.9 \pm 0.5$ \\
\hline $\mathrm{PO}_{4}^{-3}-\mathrm{P}(\mathrm{mg} / \mathrm{l})$ & $11.02 \pm 0.5$ & $8.6 \pm 0.5$ & $10.1 \pm 0.2$ & $8.2 \pm 0.3$ \\
\hline $\mathrm{pH}$ & $7.0 \pm 0.5$ & $7.0 \pm 0.5$ & $7.0 \pm 0.5$ & $7.4 \pm 0.5$ \\
\hline $\begin{array}{l}\mathrm{Conductivity} \\
(\mu \mathrm{S} / \mathrm{cm})\end{array}$ & $380 \pm 0.2$ & $321 \pm 0.2$ & $390 \pm 0.5$ & $413 \pm 0.3$ \\
\hline
\end{tabular}

Table 5: Fish processing wastewater characteristic at collection point (results obtained within 3 hours after sampling) for PBM module experiment.

\begin{tabular}{|l|c|c|c|c|}
\hline \multirow{2}{*}{ Measured values } & \multicolumn{3}{|c|}{$\begin{array}{c}\text { Mean values for parameters measure } \\
\text { after 3 months }\end{array}$} \\
\hline & $\begin{array}{c}\text { September } \\
\mathbf{2 0 1 9}\end{array}$ & $\begin{array}{c}\text { October } \\
\mathbf{2 0 1 9}\end{array}$ & $\begin{array}{c}\text { November } \\
\mathbf{2 0 1 9}\end{array}$ & $\begin{array}{c}\text { December } \\
\mathbf{2 0 1 9}\end{array}$ \\
\hline $\mathrm{NH}_{4}^{+}-\mathrm{N}(\mathrm{mg} / \mathrm{l})$ & $9.7 \pm 0.6$ & $10.2 \pm 0.2$ & $9.2 \pm 0.5$ & $10.2 \pm 0.1$ \\
\hline $\mathrm{NO}_{3}^{-}-\mathrm{N}(\mathrm{mg} / \mathrm{l})$ & $19.6 \pm 0.2$ & $23.6 \pm 0.5$ & $20.8 \pm 0.2$ & $22.7 \pm 0.3$ \\
\hline $\mathrm{PO}_{4}^{-3}-\mathrm{P}(\mathrm{mg} / \mathrm{l})$ & $16.8 \pm 0.5$ & $17.3 \pm 0.4$ & $16.5 \pm 0.3$ & $12.3 \pm 0.1$ \\
\hline $\mathrm{pH}$ & $7.0 \pm 0.5$ & $7.0 \pm 0.5$ & $7.0 \pm 0.5$ & $7.2 \pm 0.5$ \\
\hline $\mathrm{Conductivity}(\mu \mathrm{s})$ & $556 \pm 0.5$ & $553 \pm 0.2$ & $557 \pm 0.6$ & $628 \pm 0.5$ \\
\hline
\end{tabular}

Table 6: Fish process wastewater characteristics in the feed tank for the PBM module experiment.

\begin{tabular}{|l|c|c|c|c|}
\hline \multicolumn{1}{|c|}{$\begin{array}{c}\text { Measured } \\
\text { parameters }\end{array}$} & \multicolumn{4}{|c|}{ Mean values for parameters measure after 3 } \\
months
\end{tabular}

had initial Water Permeability (WP) slightly higher at the start of the experiment varying between $39-34 \mathrm{~L} /\left(\mathrm{m}^{2 \times} \mathrm{h}\right.$ bar $)$. This might have been caused by swelling of membrane pores when the membranes are immersed in water, a phenomenon that could make the pore size smaller thus increasing resistance to the flow of influent. However, from day 10, the WP for PBM membrane was varying between 22 $24 \mathrm{~L} /\left(\mathrm{m}^{2 *} \mathrm{~h}\right.$ bar) illustrated (blue line) in figure 6 and was relatively constant with low fluctuations observed during the acclimation phase. A comparison of the two tested membranes showed a large difference right from the acclimation period and with WP varying between 22$39 \mathrm{~L} /\left(\mathrm{m}^{2 *} \mathrm{~h}\right.$ bar) (blue line) for the PBM module in comparison to 56- $61 \mathrm{~L} /\left(\mathrm{m}^{2} \mathrm{~h}\right.$ bar) observed for PES module illustrated by (black line) respectively. TMP of the PBM coated module was in the range of $230 \pm 1$ mbar to $200 \pm 1$ mbar in comparison to $130 \pm 1$ and 120 \pm 1 mbar observed after acclimation with PES commercial modules. These results are in agreement with the observations made from the WP experiment conducted using the cross flow test (illustrated in paragraph 3.4) where the PBM membrane exhibited low WP in comparison to the PES membrane. A reduction in membrane pore size caused by the PBM layer was attributed to low WP and low flux observed for the PBM coated membrane. These results have also been confirmed by Deowan SA, et al. [6]. The author worked on surface modification of PES membranes through the PBM technique using the REDOX polymerization technique and UV-LED polymerization technique respectively. In this study, the mean values for TMP, WP, and flux for the two tested modules were significantly different from $\left(\mathrm{t}_{\text {calculated }}>\mathrm{t}_{\text {critical }}\right)$ for paired T-test (at $95 \%$ confidence level) as illustrated in table 7.

Critical flux experimental results for PBM coated membrane module and PES membrane module: Critical flux measurement was conducted to determine the ability of PES and PBM modules to resist fouling. The results observed are shown in figure 7.

As illustrated in figure 7 , the MBR was operated by increasing the speed of the suction pump from $0.5 \mathrm{~V}$ ( $25.3 \mathrm{ml} /$ minute) to 1.11 $\mathrm{V}(55.6 \mathrm{ml} / \mathrm{minute})$ with time intervals of 24 hours (where $5000 \mathrm{ml} /$ minute $=99$ Volts). The initial flux for PES and PBM module was $5.6 \mathrm{~L} /$ $\mathrm{m}^{2} \mathrm{~h}$ (black line) and $4.4 \mathrm{~L} / \mathrm{m}^{2 *} \mathrm{~h}$ (red line) respectively. The critical flux of the PES module was observed at $7.3 \mathrm{~L} / \mathrm{m}^{2 *} \mathrm{~h}$ with TMP of 230 mbar. Above this point, a decrease in flux and the onset of fouling was observed. The PBM module, however, had a relatively constant flux during the experimental period the critical flux was not achieved at TMP up to 340 mbar. From the experimental results it might be expected to operate the PBM membrane module above 350 mbar at higher flux than the commercial one without having achieved critical flux. However, this needs to be further studied. These findings are in line with what was reported Deowan SA, et al. [6]. The author studied the critical flux for PES membranes and PBM membranes using model textile dye wastewater.

\section{COD removal efficiency for PES module and PBM module}

The performance of the PES membrane module and PBM membrane module in terms of COD removal efficiency was compared as shown in figure 8.

Figure 8 indicates good biodegradation and better performance for the PBM membrane module with constant and high removal efficiency for COD varying from $95 \%$ to $97 \%$ from start phase and for the entire duration in comparison to $92 \%-95 \%$ observed with PES membrane module. Stable values for COD in permeate were noted varying from $100 \mathrm{mg} / \mathrm{L}$ to $61.7 \mathrm{mg} / \mathrm{L}$ for the PBM membrane module

Citation: Mburu J, Gukelberger E, Mwangi P, Kinyua R, Galiano F, et al. (2020) Application of Novel Low-Fouling Membranes for Fish Processing Wastewater Treatment and Comparison to PES Commercial Membranes in a Lab Scale Membrane Bioreactor. Int J Water Wastewater Treat 6(1): dx.doi.org/10.16966/2381-5299.166 


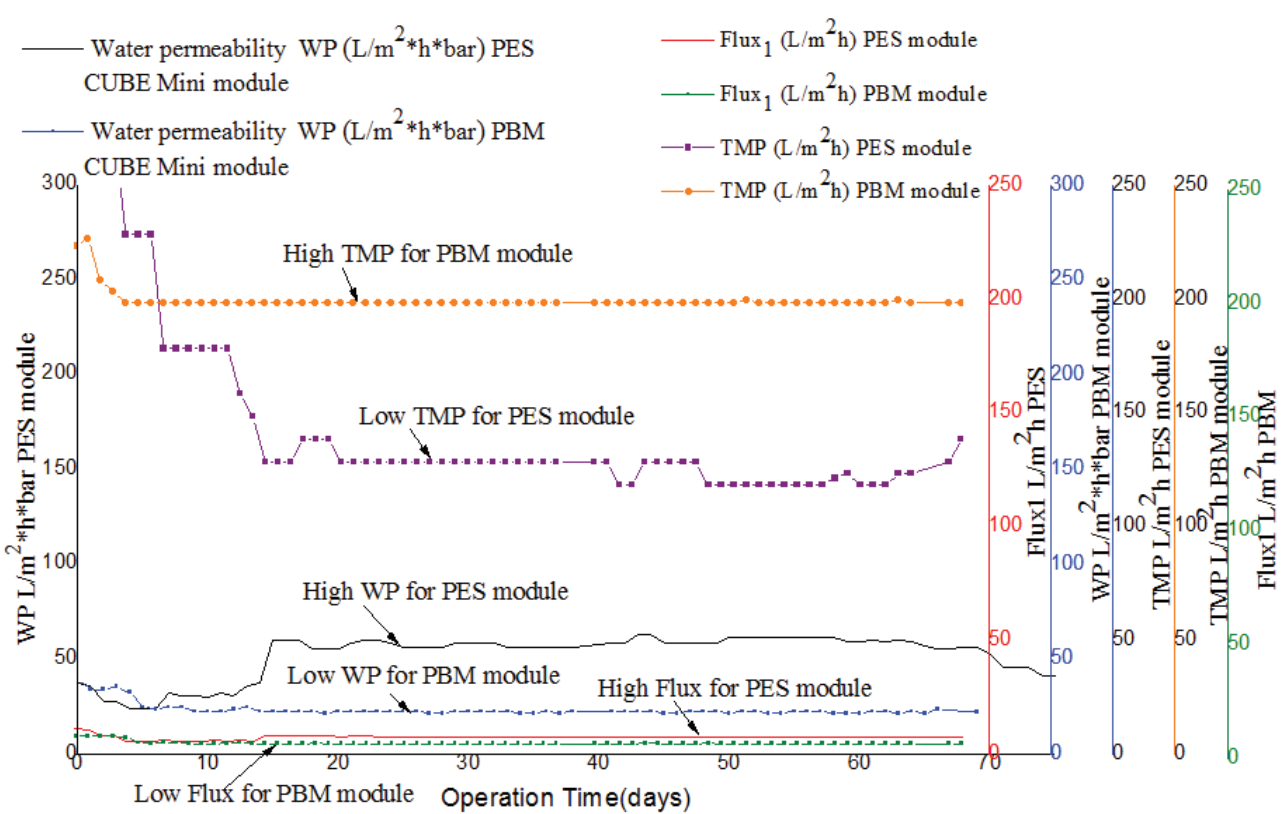

Figure 6: Comparison of water permeability (WP), flux and transmembrane pressure (TMP) with operation time (days) for PES module and PBM module.

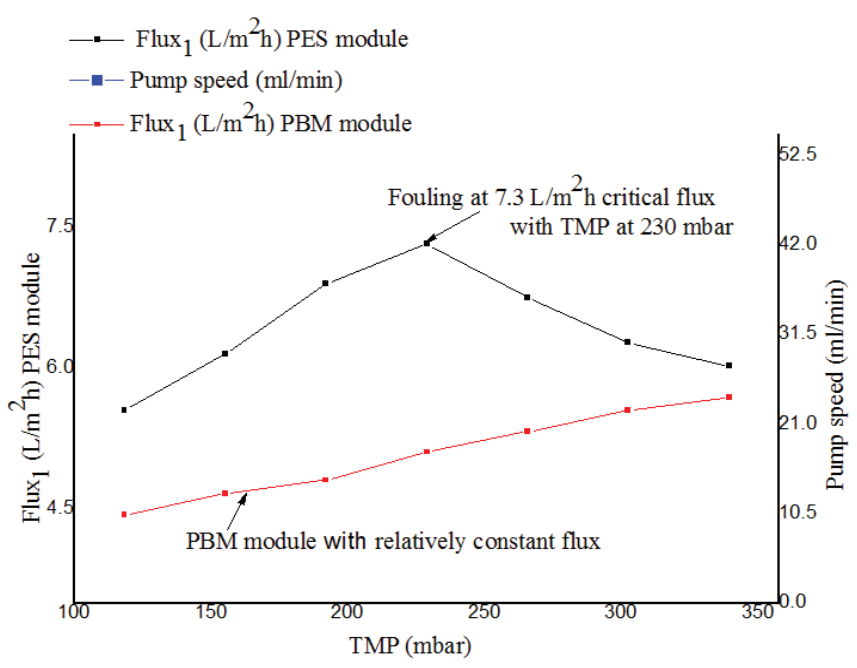

Figure 7: Critical flux measurement for PES module and PBM module.

from the start phase and for the entire duration when the experiment was conducted. On the other hand, the PES module was characterized by fluctuations of permeate COD varying after acclimation from 123 $\mathrm{mg} / \mathrm{L}$ to $78.0 \mathrm{mg} / \mathrm{L}$. The better performance of the PBM module might have resulted from the higher residence time (HRT) (38.4-45.7 h) in the reactor in comparison to (27.4-29.0 h) for PES module, this was attributed to lower flux for the system operated with PBM module as illustrated in figure 9. High residence time (HRT) and increased food to microorganism $(\mathrm{F} / \mathrm{M})$ ratio in the reactor increases biodegradation of the biomass and results in improved COD removal efficiency and better performance of the system. These findings are in agreement with what was reported by the author Galiano F, et al. [9]. The author used textile dye wastewater for testing PBM coated membranes. For this study, COD levels in permeate collected from the two tested PES and PBM module systems were mainly within the maximum allowable concentration of $<100 \mathrm{mg} / \mathrm{L}$ as per the WHO guidelines for wastewater reuse for irrigation [17]. However, the two tested PES and PBM modules showed a significant difference in their mean values for COD concentration in permeate with $\left(\mathrm{t}_{\text {calculate }}>\mathrm{t}_{\text {critical }}\right)$ for paired T-test (at $95 \%$ confidence level) as illustrated in table 8 .

Also to be noted for the two tested membrane modules, the HRT remained relatively constant with fluctuations observed only at the beginning of each of the experiments. However, the PBM module exhibited a higher residence time varying between $38.4 \mathrm{~h}-45.7 \mathrm{~h}$ as seen in figure 3.7 (black dotted line) in comparison to the PES module 
Table 7: Results showing a comparison of TMP for PBM module and PES membrane module (One-way, paired test, $\mathrm{n}=0.05$ ).

\begin{tabular}{|l|c|c|c|}
\hline $\begin{array}{l}\text { Operation time (days) after } \\
\text { acclimation period }\end{array}$ & Mean TMP (bar) & $\begin{array}{c}\text { Mean and STDEV for TMP, } \\
\text { Flux and WP between the } \\
\text { tested modules }\end{array}$ & $\mathbf{t}_{\text {calculated }}$ \\
\hline TMP for PES membrane module & $147.9 \pm 34.5$ & TMP (PES - PBM module) & 10.4 \\
\hline TMP for PBM membrane module & $204.0 \pm 9.3$ & & 2.78 \\
\hline Flux for PES membrane module & $7.2 \pm 0.7$ & Flux (PES - PBM module) & 3.5 \\
\hline Flux for PBM membrane module & $4.9 \pm 1.1$ & & 2.78 \\
\hline WP for PES membrane module & $57.6 \pm 4.7$ & WP (PES - PBM module) & 11.8 \\
\hline WP for PBM membrane module & $24.7 \pm 4.8$ & & 2.78 \\
\hline
\end{tabular}

Table 8: COD concentration in permeate for PES module and PBM module results (One-way, paired test, $n=0.05$ ).

\begin{tabular}{|l|c|c|c|}
\hline \multicolumn{1}{|c|}{ Operation time (days) } & $\begin{array}{c}\text { Mean and STDEV COD in } \\
\text { permeate (kg/L) }\end{array}$ & $\begin{array}{c}\text { Comparison of COD in permeate, } \\
\text { fortest conducted with PES and PBM } \\
\text { membrane modules }\end{array}$ & PES-PBM \\
\hline $\begin{array}{l}\text { From day } 21 \text { to } 91 \text { after acclimation period } \\
\text { with PES membrane module }\end{array}$ & $96.3 \pm 9.8$ & 2.78 \\
\hline $\begin{array}{l}\text { From acclimation to day } 60 \text { with PBM } \\
\text { membrane module }\end{array}$ & $71.3 \pm 12$ & \\
\hline
\end{tabular}

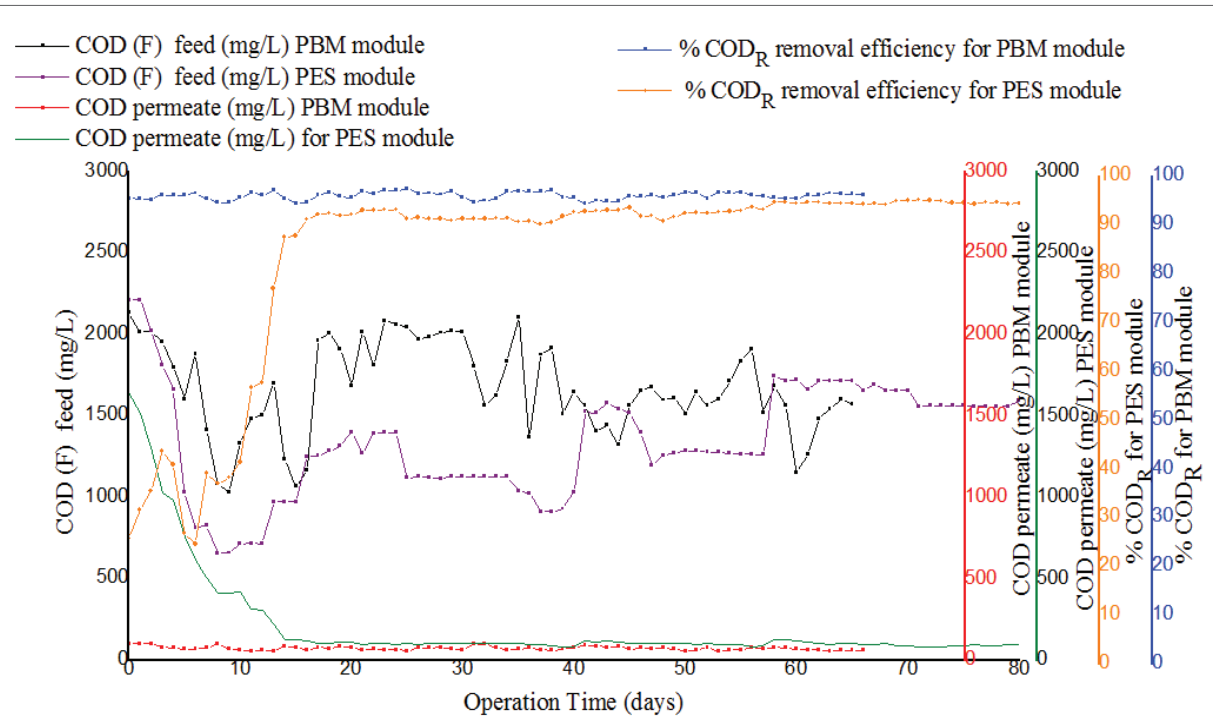

Figure 8: Comparison of COD in feed, effluent and COD removal efficiency for PES module and PBM module.

whose residence time was low (green line) and was between $27.4 \mathrm{~h}$ $-31.7 \mathrm{~h}$. The COD removal efficiency of PES membrane was at the beginning rather low and achieved $90 \%$ only after day 18 and the HRT fluctuated. The COD removal efficiency of PBM membrane showed high values $>90 \%$ right after start despite fluctuating HRT until day 10 (Figure 9).

\section{Experimental results for nitrogenous compounds removal using PES membrane and PBM coated membrane}

Removal efficiency for nitrogenous compounds in the treatment system was determined by measuring the concentration of nitratenitrogen $\left(\mathrm{NO}_{3}{ }^{-} \mathrm{N}\right)$ and ammonium-nitrogen $\left(\mathrm{NH}_{4}{ }^{+} \mathrm{N}\right)$ in the feed and in permeate. Figures 10 and 11 illustrate results observed from the two tested PES and PBM modules, respectively.

As illustrated in figure 10 and 11 the concentration of $\mathrm{NO}_{3}^{-}-\mathrm{N}$ and $\mathrm{NH}_{4}^{+}-\mathrm{N}$ in the raw fish processing wastewater varied at the collection point and in the feed tank a phenomenon attributed to the anoxic and anaerobic conditions in the feed tank as was discussed in paragraph 3.5. The two tested membranes demonstrated good removal efficiency for nitrogenous compounds in permeate. However, the PBM membrane had better performance with an average percentage removal efficiency of $88 \pm 1 \%$ as compared to $85 \pm 2 \%$ observed with the PES membrane which might be due to longer HRT. The two tested systems had nitratenitrogen $\mathrm{NO}_{3}{ }^{-} \mathrm{N}$ in permeate mainly within an acceptable range of

Citation: Mburu J, Gukelberger E, Mwangi P, Kinyua R, Galiano F, et al. (2020) Application of Novel Low-Fouling Membranes for Fish Processing Wastewater Treatment and Comparison to PES Commercial Membranes in a Lab Scale Membrane Bioreactor. Int J Water Wastewater Treat 6(1): dx.doi.org/10.16966/2381-5299.166 


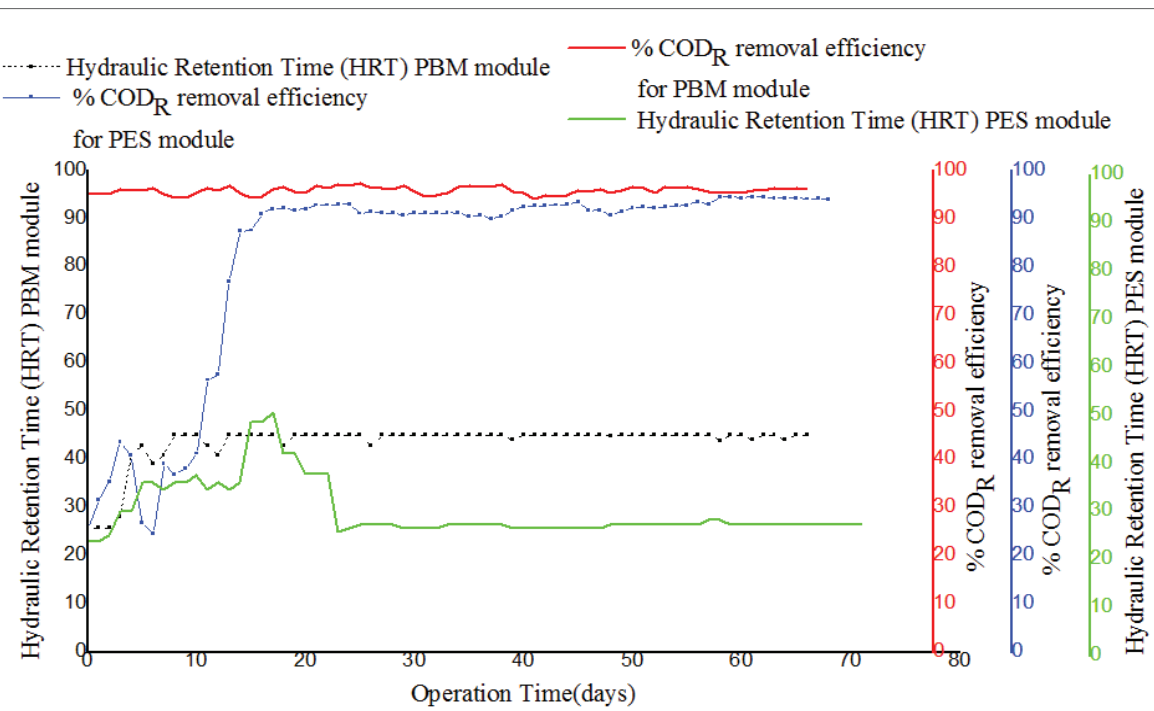

Figure 9: Comparison of HRT and COD removal efficiency with operation time for PES membrane module and PBM membrane module.

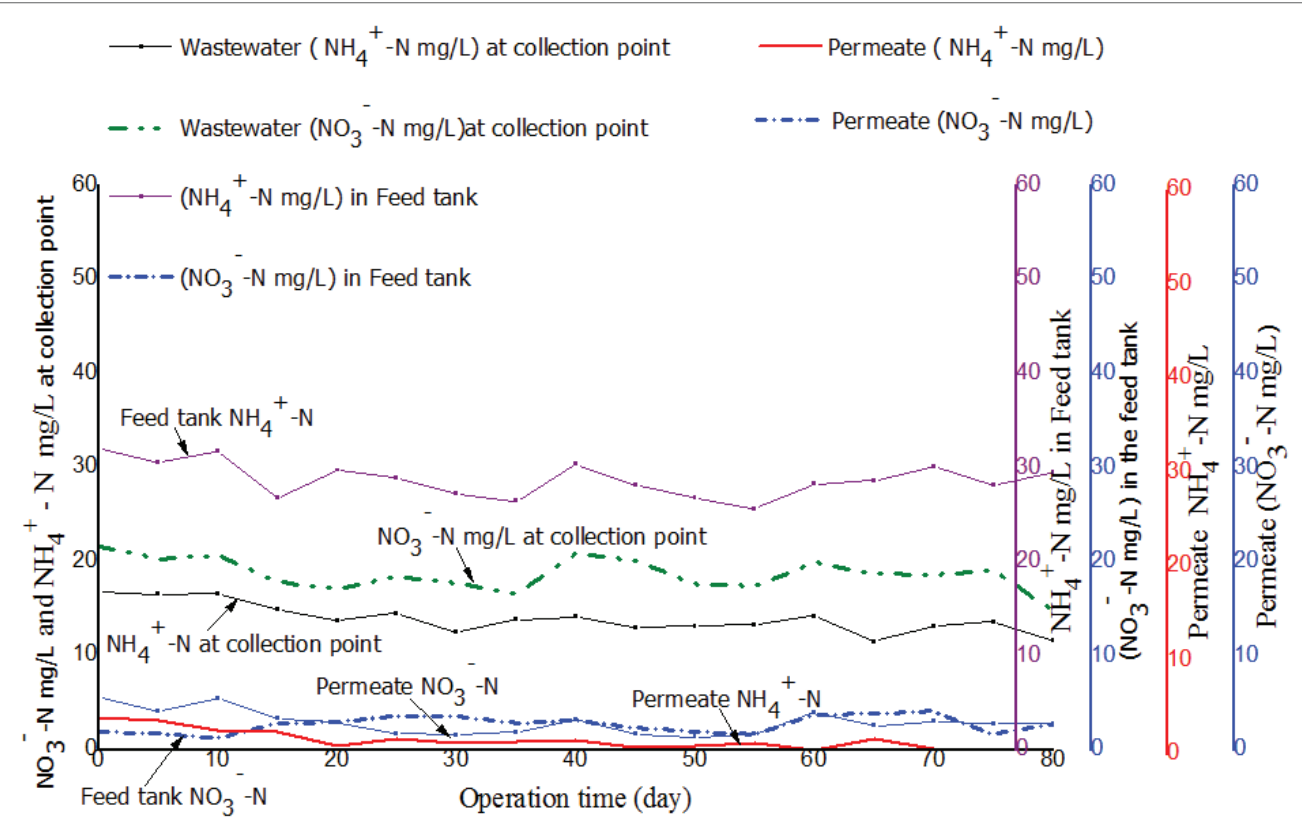

Figure 10: Comparison of ammonium-nitrogen $\left(\mathrm{NH}_{4}^{+}-\mathrm{N}\right)$ and nitrate-nitrogen $\left(\mathrm{NO}_{3}{ }^{-} \mathrm{N}\right)$ in the feed and in permeate for the PES module.

5 to $30 \mathrm{mg} / \mathrm{L}$ as per the WHO guidelines for wastewater reuse for irrigation [17]. However, the mean concentration for $\mathrm{NH}_{4}^{+}-\mathrm{N}$ and $\mathrm{NO}_{3}^{-}-\mathrm{N}$ in permeate for the two tested (PES and PBM) modules had a significant difference with $\left(\mathrm{t}_{\text {calculated }}>\mathrm{t}_{\text {critical }}\right)$ for paired T-test (at $95 \%$ confidence level) as illustrated in table 9.

\section{Comparison of the performance of PES membrane and PBM membrane in terms of phosphates removal efficiency}

For this experiment, $55.2 \mathrm{mg} / \mathrm{L}$ of Alum as Aluminum sulphate $\mathrm{Al}_{2}$ $\left(\mathrm{SO}_{4}\right)_{3} \cdot 18 \mathrm{H}_{2} \mathrm{O}$ was continuously added into the denitrification tank for a period of 30 minutes whenever the wastewater was replaced. This was carried out to facilitate precipitation of soluble phosphates into large particles that remained in the activated sludge and were removed with surplus sludge. The flow rate of the wastewater was recycled between the aeration tank and anoxic tank throughout the period when the experiment was conducted. The level of $\mathrm{PO}_{4}^{3-}-\mathrm{P}$ in feed and in permeate was evaluated for the two experiments conducted using PBM and PES modules. The performance of the tested modules was compared as illustrated in figure 12 .

The two tested membranes showed good performance for removal of $\mathrm{PO}_{4}^{3-}-\mathrm{P}$ with an average percentage removal efficiency of $69 \pm$ $3 \%$ for PES and $84 \pm 1 \%$ for PBM membranes respectively. As seen in figure 12, the $\mathrm{PBM}$ coated module had lower levels of $\mathrm{PO}_{4}^{3-}-\mathrm{P}$ in permeate ranging from $1.3 \pm 0.1 \mathrm{mg} / \mathrm{L}$ to $2.6 \pm 0.2 \mathrm{mg} / \mathrm{L}$ (blue line) in comparison to $5.02 \pm 0.1 \mathrm{mg} / \mathrm{L}$ to $1.83 \pm 0.04 \mathrm{mg} / \mathrm{L}$ (green line) observed with PES membrane modules. The two tested membranes

Citation: Mburu J, Gukelberger E, Mwangi P, Kinyua R, Galiano F, et al. (2020) Application of Novel Low-Fouling Membranes for Fish Processing Wastewater Treatment and Comparison to PES Commercial Membranes in a Lab Scale Membrane Bioreactor. Int J Water 
Table 9: $\mathrm{NH}_{4}^{+}-\mathrm{N}$ concentration in permeate for PES module and PBM membrane module results (One-way, paired test, $\left.\mathrm{n}=0.05\right)$.

\begin{tabular}{|c|c|c|c|c|}
\hline Membrane & $\begin{array}{c}\text { Mean and STDEV } \mathrm{NH}_{4}^{+}-\mathrm{N} \text { level in } \\
\text { permeate }(\mathrm{mg} / \mathrm{L})\end{array}$ & $\begin{array}{l}\text { Comparison of } \mathrm{NH}_{4}^{+}-\mathrm{N} \text { in permeate between } \\
\text { PES and PBM membrane }\end{array}$ & $\mathbf{t}_{\text {calculated }}$ & $t_{\text {critical }}$ \\
\hline $3^{\text {rd }}$ phase with PES membrane & $4.9 \pm 1.8$ & $3^{\text {rd }}$ phase $M_{1}-5^{\text {th }}$ phase & 4.11 & 2.78 \\
\hline \multirow[t]{2}{*}{$5^{\text {th }}$ phase with PBM membrane } & $0.6 \pm 0.2$ & & & \\
\hline & $\begin{array}{c}\text { Mean and STDEV } \mathrm{NO}_{3}^{-}-\mathbf{N} \text { level in } \\
\text { permeate }(\mathrm{mg} / \mathrm{L})\end{array}$ & $\begin{array}{l}\text { Comparison of } \mathrm{NO}_{3}^{-}-\mathbf{N} \\
\text { in permeate between PES and PBM } \\
\text { membrane }\end{array}$ & $\mathrm{t}_{\text {calculated }}$ & $\mathrm{t}_{\text {critical }}$ \\
\hline $3^{\text {rd }}$ phase with PES membrane & $3.3 \pm 1.2$ & $1^{\text {st }}$ phase $M_{1}-3^{\text {rd }}$ phase $M_{2}$ & 5.44 & 2.78 \\
\hline $5^{\text {th }}$ phase with PBM membrane & $0.9 \pm 0.5$ & & & \\
\hline
\end{tabular}

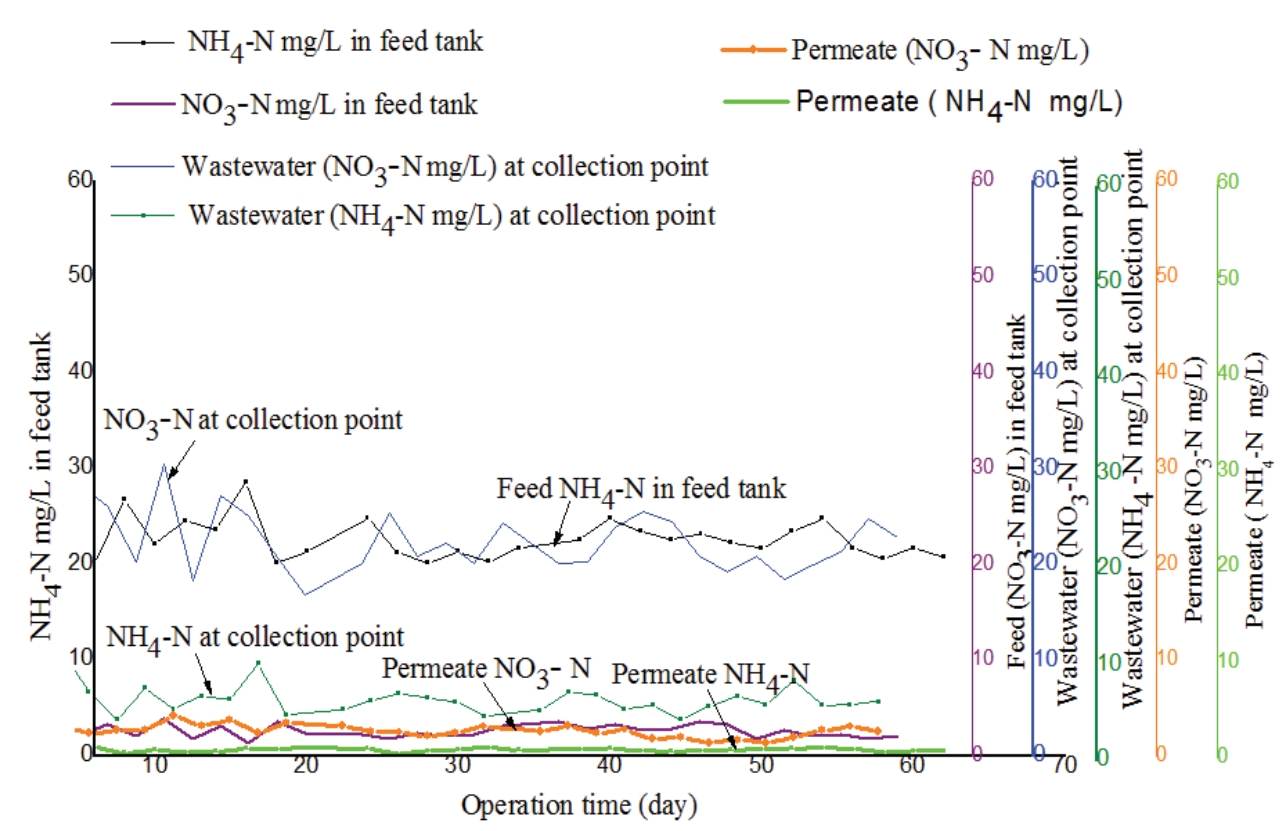

Figure 11: Comparison of ammonium-nitrogen ( $\left.\mathrm{NH}_{4}+-\mathrm{N}\right)$ and nitrate-nitrogen $\left(\mathrm{NO}_{3}^{-}-\mathrm{N}\right)$ in the feed and in permeate for the PBM-coated membrane module.

had $\mathrm{PO}_{4}^{3-} \mathrm{P}$ in permeate lowered to an acceptable range of $\leq 5 \mathrm{mg} / \mathrm{L}$ as per the WHO guidelines for wastewater reuse for irrigation [17].

\section{Conclusion}

This work aimed at preparing and applying a novel low-fouling membrane for the first time for the treatment of fish processing wastewater with a Membrane BioReactor (MBR) system. This was achieved by coating the surface of a commercial PolyEtherSulphone (PES) membrane using a Polymerizable Bicontinuous Microemulsion (PBM) technique. The IR spectrums confirmed the presence of PBM coating on the coated membranes thus confirming a successful coating process. Low contact angles indicated that hydrophilic property was achieved for the modified PBM membrane as was demonstrated with contact angle measurements. The PBM coated membranes had better resistance to fouling as was demonstrated through the cross-flow fouling test with humic acid as model compound that showed low color intensity deposited on PBM coated membrane. This was further confirmed with iMBR experimental results that showed higher critic flux for the PBM module compared to the commercial one. The PES membrane module showed significant fouling with a critical flux of $7.3 \mathrm{~L} / \mathrm{m}^{2} \mathrm{~h}$ at TMP of $230 \mathrm{mbar}$. For the PBM coated module no critical flux was achieved up to 340 mbar. The PBM coated module showed higher average COD removal efficiency of $96 \pm 1.1 \%$ in comparison to $92 \pm 4.9 \%$ observed with the PES membrane module. However, for both of the two tested membranes COD in permeate was mainly within the maximum allowable concentration of $<100 \mathrm{mg} / \mathrm{L}$ as per the WHO guidelines for wastewater reuse for irrigation [17]. The level of nitrate-nitrogen and soluble phosphates in permeate for the two tested modules was within an acceptable range of 5 to $30 \mathrm{mg} / \mathrm{L}$ for $\mathrm{NO}_{3}^{-}-\mathrm{N}$ and $\leq 5 \mathrm{mg} / \mathrm{L}$ for $\mathrm{PO}_{4}{ }^{3-}-\mathrm{P}$ as per the WHO guidelines for wastewater reuse for irrigation [17]. However, the PBM membrane demonstrated better performance for the removal of nitrogenous compounds and dissolved $\mathrm{PO}_{4}^{3-}-\mathrm{P}$ with a percentage removal efficiency of $88.1 \pm 1 \%$ and $83.6 \pm 1 \%$ respectively as compared to $84.5 \pm 2 \%$ and $69.3 \pm 3 \%$

Citation: Mburu J, Gukelberger E, Mwangi P, Kinyua R, Galiano F, et al. (2020) Application of Novel Low-Fouling Membranes for Fish Processing Wastewater Treatment and Comparison to PES Commercial Membranes in a Lab Scale Membrane Bioreactor. Int J Water 


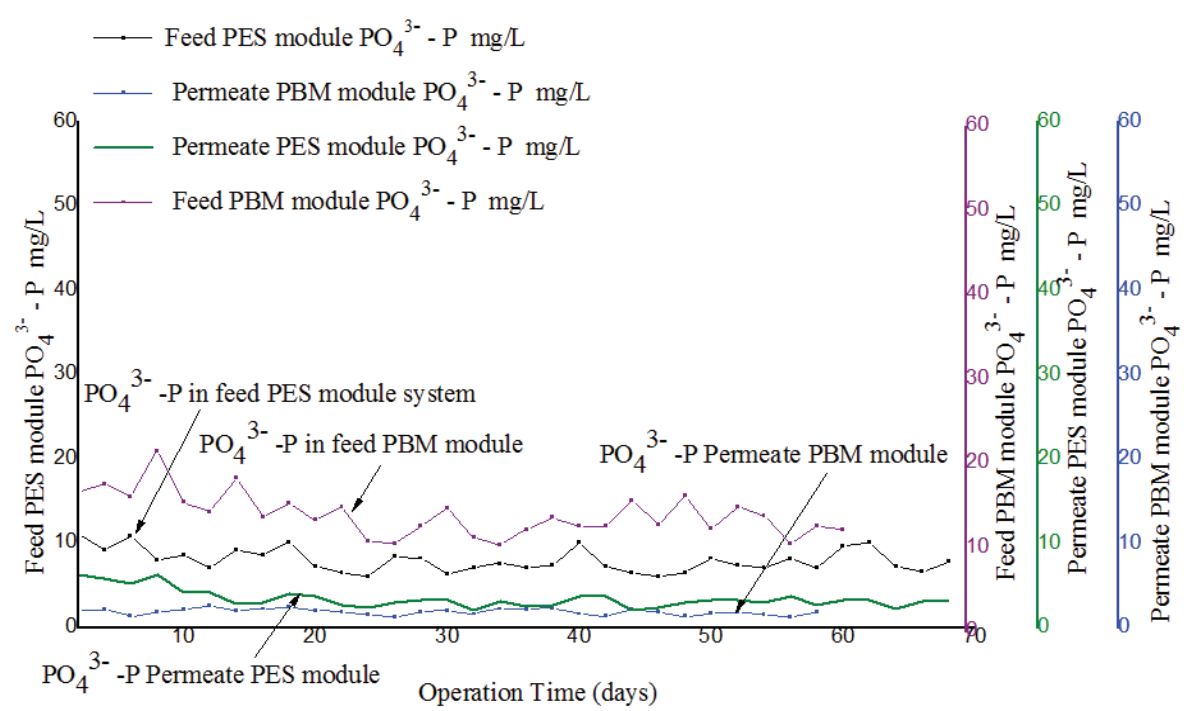

Figure 12: Comparison of phosphate $\left(\mathrm{PO}_{4}^{3-}-\mathrm{P}\right)$ in feed and in permeate for experiment conducted with PES membrane module and PBM-coated membrane module.

observed with PES membrane respectively. The PBM module was therefore confirmed to have improved performance and ability to resist fouling for a longer time in comparison to PES module. Overall this study demonstrated an improved performance of the PBM coated module vs. the commercial one what is worth to be further studied. The findings look promising to develop a low-fouling PBM coating which offers more efficient and economical treatment of fish processing wastewater in iMBR for the production of effluent to be used for irrigation agricultural fields.

\section{Acknowledgement}

This research has received funding from the European Union's Horizon 2020 research and innovation program under grant agreement number 689427 for the project VicInAqua.

\section{References}

1. Juma DW, Wang H, Li F (2014) Impacts of population growth and economic development on water quality of a lake: Case study of Lake Victoria Kenya water. Environ Sci Pollut Res 21: 5737-5746.

2. Mara D (2013) Domestic wastewater treatment in developing countries. Routledge 1-210.

3. Gichuru N, Nyamweya C, Owili M, Mboya D, Robert W (2017) Poor management of Lake Victoria fisheries (Kenya); a threat to sustainable fish supplies. Nature Faune Journal 32: 38-42.

4. Obiero KO, Abila RO, Njiru MJ, Raburu PO, Achieng AO, et al. (2015) The challenges of management: Recent experiences in implementing fisheries co-management in Lake Victoria, Kenya. Lakes Reserv 20: 139-154.

5. EMCA (1999) The Environmental Management And Co-Ordination Act.

6. Deowan SA, Galiano F, Hoinkis J, Johnson D, Altinkaya SA, et al. (2016) Novel low-fouling membrane bioreactor (MBR) for industrial wastewater treatment. J Membr Sci 510: 524-532.

7. Luong TV, Schmidt S, Deowan SA, Hoinkis J, Figoli A, et al. (2016) Membrane bioreactor and promising application for textile industry in Vietnaum. Procedia CIRP 40: 419-424.
8. Figoli A, Hoinkis J, Gabriele B, De Luca G, Galiano F, et al. (2014) Bicontinuous Microemulsion Polymerized Coating for Water Treatment. Patent Application WO2014/EP070603.

9. Galiano F, Figoli A, Deowan SA, Johnson D, Altinkaya SA, et al. (2015) A step forward to a more efficient waste water treatment by membrane surface modification via polymorizable biocontinues microemulsion. J Membr Sci 482: 103-114.

10. Mburu J, Hoinkis J, Njogu P, Kinyua R, Gukelberger E, et al. (2019) Pilot Trials on Testing and Optimization of Polyethersulfone Membranes for Treatment of Fish Processing Wastewater through Membrane Bioreactor Technology. Int J Water Wastewater Treat 5: 1-10.

11. Tang LC, Zhao L, Guan LZ (2017) 7 Graphene/Polymer Composite Materials: Processing, Properties and Applications. Ehsan Bafekrpour Edition, Advanced Composite Materials: Properties and Applications 349-419.

12. Bokhary A, Tikka A, Leitch M, Liao B (2018) Membrane Fouling Prevention and Control Strategies in Pulp and Paper Industry Applications: A Review. J Membr Sci Res 4: 181-197.

13. Kochkodan V, Johnson D, Hilal N (2014) Polymeric membranes: surface modification for minimizing (bio) colloidal fouling. Adv Colloid Interface Sci 206: 116-140.

14. Galiano F, Schmidt SA, Ye X, Kumar R, Mancuso R, et al. (2018) UV-LED induced bicontinuous microemulsions polymerisation for surface modification of commercial membranes. Enhancing the antifouling properties. Sep Purif Technol 194: 149-160.

15. Mancuso R, Amuso R, Armentano B, Grasso G, Rago V, et al. (2017) Synthesis and Antibacterial Activity of Polymerizable Acryloyloxyalkyltriethyl Ammonium Salts. ChemPlusChem 82: 12351244.

16. Li Q, Pan X, Qu Z, Zhao X, Jin Y, et al. (2013) Understanding the dependence of contact angles of commercially RO membranes on external conditions and surface features. Desalination 309: 38-45.

17. WHO (2006) World Health Organization (WHO) Guidelines for the safe use of wastewater, Excreta and Greywater. United Nations Environment Program 4.

Citation: Mburu J, Gukelberger E, Mwangi P, Kinyua R, Galiano F, et al. (2020) Application of Novel Low-Fouling Membranes for Fish Processing Wastewater Treatment and Comparison to PES Commercial Membranes in a Lab Scale Membrane Bioreactor. Int J Water Wastewater Treat 6(1): dx.doi.org/10.16966/2381-5299.166 